\title{
RECENZJE
}

Klio. Czasopismo poświęcone dziejom Polski i powszechnym PL ISSN 1643-8191, t. 28 (1)/2014, s. 209-264

\section{Człowiek w antycznym świecie, red. Sławomir Sprauski, Towarzystwo Wydawnicze „Historia Iagellonica”, Kraków 2012, ss. 430}

\section{(c) (1) $\Theta$}

\begin{abstract}
A leksander Krawczuk to bez wątpienia nestor społeczności polskich badaczy antyku, tak z racji swojego wieku, jak również dorobku naukowego oraz popularyzatorskiego. Omawianą publikację ofiarowano mu z okazji 90 urodzin. Jest to zbiór osiemnastu artykułów, których tematyka koncentruje się zwykle na poszczególnych postaciach świata helleńsko-łacińskiego i obejmuje zasadniczo całą epokę starożytną. Rozpiętość czasowa jest zatem naprawdę duża: od Grecji archaicznej, przez epokę hellenistyczną i schyłek Republiki rzymskiej, do późnego antyku, czy wręcz początków średniowiecza. W jednym przypadku mamy do czynienia nawet z Cesarstwem Bizantyjskim w XI wieku. Artykuły uszeregowane są chronologicznie, od najdawniejszych zaczynając.

Przedstawione postacie nie są jednorodnym zbiorem. Ich zróżnicowanie stanowi zarazem dobre odbicie szerokich zainteresowań profesora Krawczuka. Mamy tu więc do czynienia z monarchami, innego typu samowładcami (jak tyrani), wodzami, ludźmi Kościoła albo heretykami, czyli standardowym przekrojem społecznym prezentowanym $\mathrm{w}$ badaniach z zakresu historii starożytnej. Ponadto pojawiają się filozofowie, czy lokalni potentaci - euergeci, lub arystokraci pretendujący do władzy. Plejada postaci jest więc szeroka. Rzeczywiście, jak pisze na okładce redaktor: „Są wśród nich zarówno osoby bardzo znane, jak i te z drugiego czy trzeciego planu historycznej sceny”. Wszystkie to postacie wybitne, należące do określonej
\end{abstract}


elity (nawet jeśli tylko prowincjonalnej) swoich czasów. Traktujące o nich artykuły oczywiście trudno uznać za pełne studia biograficzne. Realizacja takiego zadania byłaby zresztą nadzwyczaj trudnaze względu na ograniczenia objętościowe publikacji. Zasadniczo pojedynczy tekst z tomu koncentruje się na wybranych aspektach działalności danej postaci, przedstawiając ją w szerszym ujęciu, na tle życiorysu i uwarunkowań czasów, w których dana jednostka funkcjonowała. Dzięki temu całość jest bardziej przystępna w lekturze, dla czytelnika nie będącego specjalistą w danej tematyce.

Tytułowe hasło: „człowiek w antycznym świecie” można z pewnością uznać za bardzo ogólne i niewiele mówiące czytelnikowi. Kieruje ono naszą wyobraźnię głównie w stronę szeroko pojętej dziedziny antropologii historycznej. Omawianą pracę trudno jednak zaliczyć bezpośrednio do tego nurtu, jakkolwiek miejscami się o niego ociera. Obecne są w niej bowiem próby analizy znanych przecież postaci z nieco podobnej perspektywy, poprzez choćby podniesienie kwestii stosunków rodzinnych pomiędzy Antygonem Jednookim a jego synem Demetriuszem, na tle zwyczajów epoki. Bardzo interesujące jest tutaj zwłaszcza spojrzenie na Lucjusza Korneliusza Sullę, pod kątem jego wizerunku ulegającego zmianom wraz z upływem czasu. Zahacza ono o analizę pamięci historycznej społeczeństwa rzymskiego schyłku republiki i pryncypatu. W artykule poświęconym Ptolemeuszowi VIII, obok opisu jego rządów, odnajdujemy również wyczerpujące przedstawienie zawartego w źródłach obrazu władcy, który zostaje skonfrontowany $\mathrm{z}$ antycznymi ideałami monarchicznymi. Te również są zarysowane dla czytelnika w zwięzłej, lecz treściwej formie. Przeprowadzone badania (w tym konfrontacja przekazu pisarzy antycznych ze świadectwami zawartymi na zachowanych dokumentach papirusowych) skłaniają jednak autora ku opinii o przesadnie negatywnym wizerunku króla w historiografii starożytnej. W przypadku cesarza Juliana (zwanego Apostata), mamy do czynienia z ukazaniem jego postawy w obliczu kryzysu żywnościowego w Antiochii przed wyprawą zbrojną na Persję w 363 roku. Uwaga autora skupia się na charakterystyce działań władcy, zmierzających do zażegnania niebezpieczeństwa głodu, zwłaszcza od strony historyczno-ekonomicznej. W artykule poświęconym Kleopatrze VII położono nacisk na kreowane przez nią środowisko intelektualne. Władcę frankijskiego Chlodwiga widzimy zaś u progu jego rządów w kontekście przekazów źródłowych (Grzegorz 
z Tours i Fredegar) epizodu z „dzbanem z Soissons”. Wreszcie mamy tu rozważania dotyczące funkcji pełnionej przez małżonkę cesarza Justyniana, Teodorę, na dworze i w aparacie władzy. Autor wyraża pogląd o znaczącym jej przecenianiu przez większość badaczy oraz zastanawia się nad relacją Historii sekretnej Prokopiusza do pozostałych jego dzieł tj. O budowlach i Historii wojen.

Wiele omawianych postaci to jednak osoby mało znane większości czytelników. Czasami były one prawie (lub wręcz zupełnie) nieobecne w dotychczasowych rodzimych badaniach nad antykiem. $Z$ tego też powodu, artykuły poruszające ich losy są cennym uzupełnieniem polskiej nauki. Niektóre z nich to wspomniane wcześniej „osoby trzeciego planu”, jak Epaminondas z Akrajfii - bogaty euergeta beocki, prawdopodobnie właściciel ziemski, działający na przełomie er. Inne postacie w swych czasach odgrywały znacznie poważniejszą rolę, jednak - głównie wskutek przepadku źródeł - są nam stosunkowo słabo znane. Należy tu chociażby Archytas z Tarentu, człowiek niezwykle wręcz wszechstronny: filozof, matematyk, dowódca wojskowy oraz polityk pełniący czołowe funkcje w ojczystym mieście. Za nader ciekawy trzeba uznać tekst poświęcony osobie Histiajosa z Miletu - tyrana tego miasta, związanego nierozłącznie z powstaniem Jonów przeciwko Persji (499-494 p.n.e.). Autor skupia się na samym sposobie jego ukazania przez Herodota oraz przyczynach takiego przedstawienia. We wnikliwej analizie stwierdza, że obraz władcy został negatywnie zniekształcony przez obarczenie go odpowiedzialnością za wybuch buntu i nieszczęścia, które spadły potem na Jonów. Informacje takie mogły się wywodzić z otoczenia jego bratanka, Aristagorasa, chcącego zrzucić na niego odpowiedzialność za rozlaną krew. Niewykluczone, że Histiajos w rzeczywistości był zupełnie zdolnym władcą, dbającym w miarę możliwości o swoje miasto. W książce jest też obecny Memnon z Rodos - grecki kondotier, którego pomysłowa obrona imperium Achemenidów wymusiła daleko posunięte modyfikacje strategii Aleksandra Macedońskiego (czy też jej powstanie w ogóle, autor bowiem bardzo przekonująco udowadnia, że w momencie rozpoczęcia działań król nie dysponował nią w ogóle). Widzimy ponadto Konstantyna Dalassenosa, bizantyjskiego arystokratę z XI wieku, wodza i pretendenta do tronu cesarskiego, którego kariera publiczna została przedstawiona krótko, ale wyczerpująco. 
W całym tomie nie brakuje również ludzi religii. Czytamy bowiem o przypadku Maksyma Herona, łączącego prawowierne chrześcijaństwo z filozofią cynicką. W wyniku rozgrywek wewnątrzkościelnych został patriarchą Konstantynopola, choć tylko na jeden dzień. Z kolei Filostorgiusz to przypadek heretyka $\mathrm{z}$ mało znanego odłamu eunomian, zrzeszającego radykalnych przeciwników nicejskiego credo, wedle którego Syn Boży był zupełnie niepodobny do Ojca. Artykuł podejmuje problem sposobu, w jaki spisał on swoją (rekonstruowana) Historię Kościota.

W niektórych tekstach charakterystyka wybranych postaci była jedynie pretekstem do szerszych rozważań. Już w pierwszym artykule zbioru znajdujemy przedstawienie szerszych dociekań odnośnie do genealogii macedońskiej dynastii, a ściślej rzecz ujmując: problemu jej protoplasty. W zachowanym materiale źródłowym przewijają się bowiem imiona Perdikkasa, Archelaosa, czy Karanosa. Kłopotów przysparza też sama nazwa rodu, występującego raz jako Temenidzi, a raz jako Argeadzi. Badacz wskazuje na prawdopodobne liczne, celowe ingerencje w te kwestie samych głównych zainteresowanych (tj. władców Macedonii), spowodowane bieżącą pragmatyką polityczną. Stawia również przekonującą hipotezę, że protoplasty można by upatrywać w Argajosie, wspominanym przez Herodota, jako syn wspomnianego Perdikkasa. Przemawia za tym imię, od którego niewątpliwie można wyprowadzić patronimiczną nazwę Argeadów. Perdikkas byłby zaś późniejszym dodatkiem, wprowadzonym przez monarchę o takim samym imieniu. Autor cały czas zaznacza jednak, że nie możemy jednoznacznie uznać tej postaci za historyczną. Dalsze rozważania („Dionizjusz I i Ateńczycy”) kierują nas ku relacjom ateńsko-syrakuzańskich w pierwszej połowie IV wieku a.C., a ściślej: roli, jaką odgrywali w nich przedstawiciele świata kultury i nauki. Rzecz jasna, starania te wiązały się z licznymi komplikacjami, wynikającymi ze zmiennej sytuacji politycznej. Syrakuzański tyran utrzymywał bowiem dobre relacje ze Spartą, będącą przeciwnikiem Aten przez znaczną część tego okresu. Znajdowało to swoje odzwierciedlenie $\mathrm{w}$ zmiennych perypetiach intelektualistów przebywających na jego dworze (m.in. analizowany jest słynny przypadek Platona) oraz ich podejściu do władcy (od pochwał do bezpardonowych ataków). Również artykuł „Król a miasto. Prestiż i władza w epoce hellenistycznej” kieruje naszą uwagę w stronę rozważań natury bardziej ogólnej, dotyczącej wzajemnych 
relacji pomiędzy dwoma rodzajami podmiotów: monarchami a miastami. Zostały one opisane w kategoriach transakcji, mających przynieść obopólne korzyści. Podstawę stanowią tu trzy przypadki korespondencji pomiędzy władcą a miastem, która zachowała się w materiale epigraficznym. Z kolei tekst poświęcony aktywności politycznej rzymskiej młodzieży na szerokim tle przedstawia rolę, którą w życiu publicznym schyłkowej Republiki odgrywała grupa „młodzieńców z bródkami” o arystokratycznej proweniencji. Stanowiła ona rodzaj opozycji przeciwko wpływom członków pierwszego Triumwiratu. Uwaga badacza skupia się zwłaszcza na osobie jej nieoficjalnego przywódcy - Gajusza Skryboniusza Kuriona Młodszego.

Całościowe podsumowanie tak bogatego i niejednorodnego zbioru artykułów jest trudną sprawą. Oceny zawartości można dokonać na kilku płaszczyznach. Pierwsza to rozliczenie z wykonania samego zadania książki - mającej być wyrazem hołdu dla prof. Krawczuka. Cel ten, jak się wydaje, został osiagnięty. Różnorodność tematyczna, która w innym przypadku mogłaby być uznana za pewną wadę (można byłoby stwierdzić nawet, że to przysłowiowy „groch z kapustą”), w tym wypadku jak najbardziej ma swoje uzasadnienie. Nie można bowiem dzieła o takim charakterze rozpatrywać bez nawiązania od dorobku profesora, z którym winno się łączyć choć częściowo. Ze względu na rozległość jego zainteresowań oraz ich biograficzny charakter (dość wspomnieć poczty cesarzy rzymskich i bizantyjskich), taka tematyka recenzowanego dzieła jest jak najbardziej sensowna. Zarazem szeroki wybór postaci daje możliwość spojrzenia na starożytność jako pewną całość, co prawda w dość ograniczony sposób, lecz nie mamy tu przecież do czynienia z podręcznikiem historii. Solidnie zarysowane tło czyni pracę zrozumiałą dla nie-specjalistów, co było troską autorów, wedle deklaracji we wstępie. Temu służy również ograniczenie cytatów obcojęzycznych (zwłaszcza w językach klasycznych) oraz zapis słownictwa greckiego w formie transkrybowanej. Książka więc ma duży potencjał jako pozycja o charakterze popularyzatorskim, wprowadzającym do wielu zagadnień. Ten aspekt także ma swoje znaczenie, zwłaszcza jeśli pamiętamy o zasługach prof. Krawczuka na tym polu.

Kolejną płaszczyzną jest ocena pracy, jako opracowania naukowego. Tę najtrudniej jest zmierzyć - wszak każdy artykuł powinien być de facto traktowany osobno, w wyczerpujący sposób, na co nie pozwala restrykcyjna 
forma recenzji. Można natomiast powtórzyć opinię o stosunkowo wysokiej wartości wielu tekstów, jako dotyczących osób i zagadnień, które dotychczas w polskiej nauce nie były praktycznie poruszane. Dodatkowo, nawet w przypadku artykułów traktujących o bardziej „powszedniej” tematyce zaznacza się zwykle dążenie do mniej konwencjonalnego ujęcia tematu, co wychodzi im na dobre. Poziom merytoryczny wydaje się zasadniczo bez zarzutów we wszystkich przypadkach. Oczywiście można mieć pewne uwagi do niektórych fragmentów omawianej książki. W artykule poświęconym relacjom między Demetriuszem i Antygonem brakuje bardziej zdystansowanego stosunku do przekazów (zwłaszcza Plutarcha) dotyczących prowadzenia się tego pierwszego. Kontrowersyjna miejscami jest również ocena początków kariery wojskowej młodego Demetriusza, bagatelizująca porażki (s. 132-133). Myślenie takie nie wydaje się zbyt odpowiednie w przypadku działań skutkujących śmiercią ludzi, zwłaszcza, że byli to wyszkoleni zawodowcy. Nawet wielkie monarchie hellenistyczne nie mogły sobie pozwolić na zbyt hojne szafowanie krwią swych wykwalifikowanych wojowników. Kampanie militarne z udziałem Demetriusza były już zresztą omawiane w polskiej nauce, lecz autorka niestety nie wykazuje znajomości stanu badań w tym zakresie ${ }^{1}$. W znakomitym skądinąd tekście dotyczącym wizerunku Sulli razi użycie słowa „konserwatysta” w odniesieniu do Cycerona (s. 235). Określenie to zbyt mocno łączy się z ideologią polityczną powstałą w czasach nowożytnych, współcześnie trudnej do jednoznacznego zdefiniowania, a nie występującej przecież w świecie starożytnym. Dlatego bardziej zasadne byłoby neutralne i lepiej oddające istotę problemu określenie poglądów oratora jako zachowawczych. Natomiast artykuł poświęcony Memnonowi z Rodos mógłby jeszcze zyskać, gdyby do, i tak wnikliwej analizy, autor dołączył porównawcze odniesienie do wojny korynckiej między Persją a Spartą na przełomie V i IV stulecia a.C. Wtedy to bowiem Imperium Achemenidów z powodzeniem zastosowało strategię zbliżoną do koncepcji Rodyjczyka, co doprowadziło (jako jedna z przyczyn) do wybuchu wojny korynckiej (395-387/6 a. C.).

Od strony zewnętrznej praca również wygląda dobrze. Szyte stronnice w twardej oprawie, dobrej jakości papier i prawidłowo wykonany skład

1 T. Grabowski, Ostatni tryumf Ptolemeuszy, Kraków 2010, s. 151-162. 
sprawiają, że nie można stawiać żadnych zarzutów. Biorąc więc pod uwagę wszystko, co zostało tu powiedziane, można stwierdzić, że Człowiek $w$ antycznym świecie to książka, lekturze której warto poświęcić nieco czasu - jest godna uwagi zarówno badaczy naukowo zajmujących się epoką, jak i każdego czytelnika zainteresowanego tematem.

Wojciech Duszyński (Kraków) 